\title{
CEF Professional Profile as an Instrument in Language Needs Assessment for Business Companies
}

\author{
Elsa Zela \\ Agricultural University of Tirana, \\ Albania
}

\section{Doi: 10.2478/jesr-2018-0014}

\begin{abstract}
The switch form a centralized economy to free trade during the past two decades in Albania as well as efforts to be integrated into the European Union have led to the growing prevalence of English language, which has become the leading lingua franca for communication between experts not only at international but also national level, as various business documents, contracts, reports, etc. are largely used from Economics graduates in their daily work. This paper seeks to create a Professional Profile (P.P.)for business graduates employed mainly in manufacturing companies operating in international business. Using the P.P. of the Common European Framework of References (CEFR), it identifies English language skills that graduates of Economics, employed in business companies use more often in their working environments and the communication difficulties faced by employees in carrying out the required work. Through interviews, questionnaires and language audit, the study yields vast data on the communication situations mostly needed and used in companies in their everyday work. These data are an input for syllabus design in the field of teaching English for Specific Purposes since they lay the foundation of a syllabus which is based on the real need of the students and the labour market for English Language and communication
\end{abstract}

Keywords: ESP, Business English, CEF professional profiles, language needs

\section{Introduction}

The Common European Framework of Reference for Languages has been in the recent years a valuable instrument for achieving a European Approach to Foreign Language Learning in Higher Education, developing language syllabuses and guidelines for the curriculum in compliance with the prerequisites of the European Higher Education Area (Council of Europe, 2001). It contains references on students' needs ("real needs", "communication needs", "specific needs", "target needs", "student needs" and considers "motives" as synonyms used throughout the text 'referring to the needs of society (i.e. the needs of a multilingual and multicultural Europe).

CEFR clearly encourages the parties involved in language teaching "to base their work on the needs, motivations, characteristics and resources of the students", which means that they should answer these three questions:

"What will the learner need to do with language?" (i.e the student's needs), "what do students need to learn in order to be able to use the language to achieve these goals?" learning needs) and "what do they want to learn?" (ie, target needs).

Many efforts made to increase workforce proficiency in English language are not coordinated with the education system, are not really in line with job requirements.

ESP teaching has always been characterized by a communicative approach and based on language learning tasks. Learners are asked to fulfil tasks that are familiar to them from their 
professional environment in a foreign language. This kind of language teaching and learning makes the task primary in foreign language course.

Action-Oriented Approach adopted by CEFR makes tasks central for language learning:

"A comprehensive, transparent and coherent reference framework for language learning, teaching and assessment ... The adopted approach ... is action oriented by considering learners of a language as 'social agents' first, that is members of the society which have the task of performing under certain circumstances, in a certain environment and within a specific field of action ... language activities ... are part of a wider social context, which alone is able to give these activities meaningful comprehension. We talk about "tasks" as long as actions are carried out by one or more people using their specific competencies to achieve a certain outcome.

The evidence-based systematic analysis of needs is important in designing a course syllabus in English for Specific Purposes. A fruitful analysis should specify which communication tasks the learner should perform and secondly which discourse he / she should know in order to work in the given field

As mentioned earlier in this study, CEFR uses an approach, known as task-oriented where duties "carried out by one or more persons who strategically use their particular competencies to achieve a certain result "- meaning" tasks "- which are of primary importance in language acquisition. (Council of Europe, pg. 9)

The paper will try to design a framework of the linguistic profile required in the day-to-day business of economics graduates, the language skills required in the labour market in terms of foreign language. The results of this study will serve as raw material to be taken into consideration for the design of the Business English Syllabus at Economics faculty in the Agricultural University of Tirana (AUT).

\section{Research methodology}

The population in the study is graduates in the field of Economics, employed in business companies, mainly in managerial levels, where language skills are put into professional use. This is the context in which the gaps in language competencies are presented and can be seen through practice in daily business activities at the workplace. In the working context, employees, managers and human resource departments discover and identify the gaps and competencies of professionals employed in different job positions.

In this study, 50 employees in business companies were interviewed. The profile of respondents is mainly higher education graduates in the field of economics but also those of other fields of study engaged in management. Respondents are experienced employees and managers in various sectors in the company such as sales, marketing, public relations and finance section

The main instruments used in the study are:

a). questionnaire;

b). language audits in the type of a case study, and;

c). ethnographic observations.

The questionnaire is based on the professional profile of CEFR according to the model of Dudley-Evans \& St.John 1998 and developed by Huhtta et al.

In this study, a quantitative and qualitative approach has been used to study the English language needs of bank employees and business companies. The data were analysed according to statistical techniques and as a result the findings were objectively interpreted. The study began with the interview of two experts in the field of economics and finance employed at the Chamber of Commerce. Interviews with the two economics experts were made in order to gain a detailed description of the job performance of various positions in the business sector. Based on the interview with the experts of the field, a general idea of the size of the needs analysis was created, and a framework which would be the foundation for the creation of a semi-structured questionnaire that was administered to the population in study. The companies selected for the interview are mainly international business companies and companies that are involved in trading agreements with foreign companies.

Questionnaires obtained from the sample of 50 employees provide details and different 
aspects of their work and the language used. After collecting the questionnaires and approving the permit for the ethnographic study, a language audit was conducted where about 15 employees were interviewed for the tasks they performed in English during a typical working day. During this time, about 30 cases of language use were observed.

The case studies, interviews and language audit observations were conducted based on the Professional Profile of the Language Reference Framework.

\section{Findings and the resulting profile}

Table 1 describes the first part of the professional profile where general information about the economics graduates, participating in the study is given in relation to their education and background formation. Furthermore, the table provides details on the job positions the Business graduates usually get and the last part deals with methods used to collect the data for the designation of the profile.

Table 1: General information

\begin{tabular}{|l|l|}
\hline Field & Business and foreign trade \\
\hline Education & $\begin{array}{l}\text { Bachelor diploma in business administration, accounting, finance } \\
\text { Master Diploma in business administration, accounting, finance } \\
\text { Certificate in accounting. }\end{array}$ \\
\hline Occupation & $\begin{array}{l}\text { Accountant at finance department } \\
\text { Purchasing manager } \\
\text { Head of Human Resources } \\
\text { Assistant in Quality management } \\
\text { Head of sales department } \\
\text { Head of Marketing department }\end{array}$ \\
\hline Language & English (intermediate-advanced) B1-B2 \\
\hline $\begin{array}{ll}\text { Designed by } \\
\text { Methods used to collect } \\
\text { information } & \text { Interview with representatives from Chamber of Commerce } \\
\text { Interview with heads of human resources managers in companies } \\
\text { Semi structured interviews with employees in cement and brick } \\
\text { manufacturing companies } \\
\text { Language audit }\end{array}$ \\
\hline
\end{tabular}

Table 2 summarises occupational information about the professional activities each job performs frequently. There is a description of tasks every job requires to carry out as a part of job routine, other companies and organisation where business graduated get employed. As the main interest of the study and at the same time the most abundant data concern the job descriptions for the business graduates, since the communicative situations involved in the performance of these activities provides an input for material development, classroom activities and the ESP course design in general and $\mathrm{BE}$ in in particular.

Table 2. Occupational information

\begin{tabular}{|l|l|}
\hline $\begin{array}{l}\text { Examples of } \\
\text { professions / } \\
\text { occupations } \\
\text { / jobs }\end{array}$ & $\begin{array}{l}\text { Economics graduates employed in big manufacturing companies, ranging from assistants to } \\
\text { managers, usually work in the finance, sales, purchasing and human resources departments. } \\
\text { They are often in charge of preparing accounting statements, dealing with tax services and the } \\
\text { payroll of its employees. The respective managers supervise departments. Apart from the } \\
\text { financial records, managers deal employment contract, making business arrangements with } \\
\text { other business partners, design marketing strategies for the company products, place bids for } \\
\text { raw materials and other equipment needed in the manufacturing plants. }\end{array}$ \\
\hline $\begin{array}{l}\text { Organizations } \\
\text { or } \\
\text { companies to } \\
\text { be employed } \\
\text { in }\end{array}$ & $\begin{array}{l}\text { Economics graduates may be employed in: } \\
\text { Business companies and industries, retailing, transportation companies, } \\
\text { travel agencies, government and non-government organisations, hospitality, restaurants, } \\
\text { healthcare, banking and finance, accounting offices, tax offices, factories. }\end{array}$ \\
\hline
\end{tabular}




\begin{tabular}{|c|c|}
\hline \begin{tabular}{|l|} 
Typical job \\
descriptions
\end{tabular} & 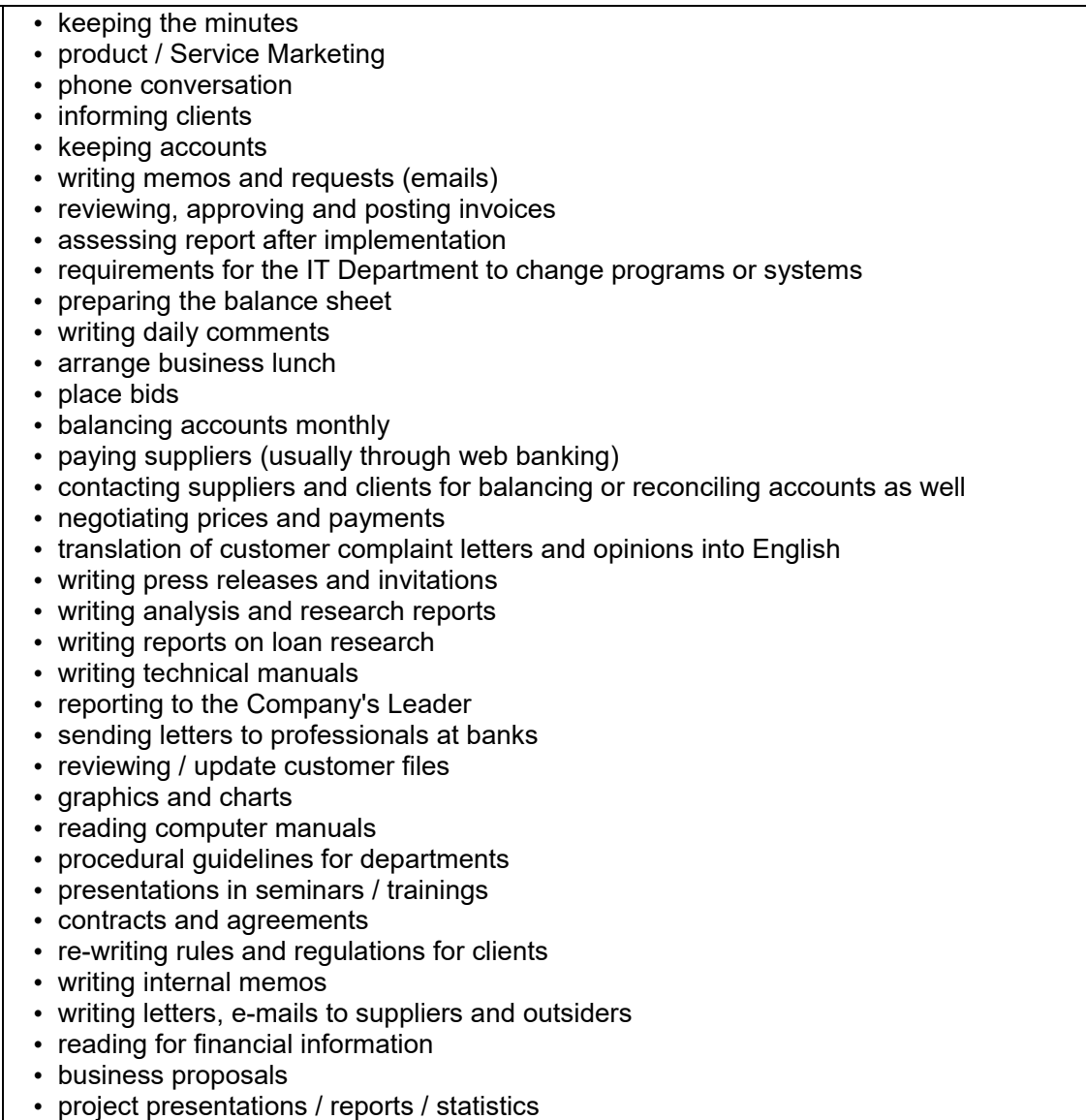 \\
\hline \begin{tabular}{|l|} 
To what \\
extent foreign \\
languages \\
are \\
needed
\end{tabular} & $\begin{array}{l}\text { Business graduates use English as the foreign language to communicate mainly for their } \\
\text { superiors who sometimes happen to be non Albanian citizen and therefore English is the } \\
\text { working language. } \\
\text { The medium of communication ranges from e-mails and phone conversation which are the } \\
\text { most common to papers, invoices, balance sheets and contracts with foreign business } \\
\text { partners. }\end{array}$ \\
\hline
\end{tabular}

The third part (Table 3) includes work context information and focuses particularly on the location that the majority of the interviewees' professional activities take place and the individuals they have business with in their everyday work life. It also contains the communication situations that those professionals encounter in their workplace, which constitutes the most extensive section of this profile part as it can provide valuable knowledge for materials development. Moreover, the text and discourse types that they deal with at work are mentioned here in order to complete their job framework.

Table 3. Location, people and communicative situations

\begin{tabular}{|l|l|}
\hline Location & $\begin{array}{l}\text { - office, purchasing department, managing accountant's office, sales department office, } \\
\text { director's office, } \\
\text { - tax office, banks, post office, labour inspection, } \\
\text { - insurance funds, }\end{array}$ \\
$\begin{array}{l}\text { - chamber of Commerce } \\
\text { c company canteen, accounts office } \\
\text { - maintenance. }\end{array}$ \\
\hline
\end{tabular}




\begin{tabular}{|c|c|}
\hline $\begin{array}{l}\text { Persons, } \\
\text { Communities, } \\
\text { Companies, } \\
\text { Institutions }\end{array}$ & $\begin{array}{l}\text { - co-workers in the same company/headquarters/affiliates, colleagues from other } \\
\text { companies, suppliers, head of account office, } \\
\text { - receptionist, head of warehouse, general manager of the company } \\
\text { - clients } \\
\text { - head of marketing/sales/ purchases department } \\
\text { - finance Personnel } \\
\text { - manager of human resources } \\
\text { - insurance agent } \\
\text { - customs officer } \\
\text { - bankers, assistant accountants, secretary of the general manger. }\end{array}$ \\
\hline $\begin{array}{l}\text { Communicative } \\
\text { Situations }\end{array}$ & 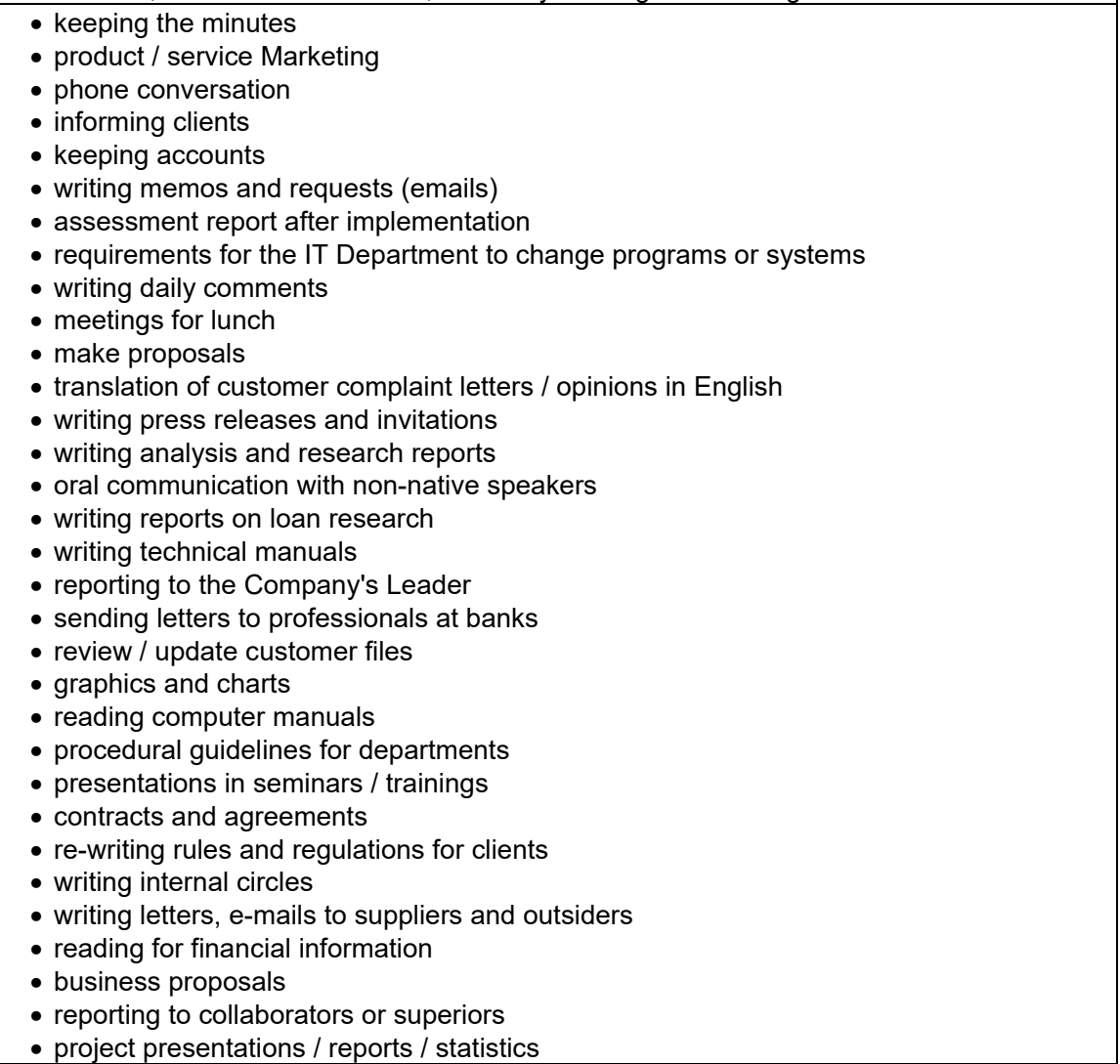 \\
\hline $\begin{array}{l}\text { Text- and } \\
\text { discourse- } \\
\text { Types }\end{array}$ & $\begin{array}{l}\text { phone calls, memos, email correspondence } \cdot \text { teleconference, reports, tax statements } \\
\text { balance sheets, computer software, invoices } \bullet \text { supplier contracts, accounting books } \bullet \\
\text { financial statements, employment contracts, payment negotiations }\end{array}$ \\
\hline
\end{tabular}

Table 4, 5 and 6 concern the most frequent routines, most demanded situations and snap shots which are part of the language audit that was carried out during the ethnographic research. They provide the real life use and the context of the communicative situations of the language for professional purposes in the business companies. 
Table 4. Most frequent routine

\begin{abstract}
Situation 1: Summary of the agreement
Communication situation: Written summary of the agreement reached over the phone

Location: Office (brick manufacturing and exporting plant)

People: Head of sales department

Critical factors for success: To start, the head of the department has to listen to the conversation on the phone and should not compromise while negotiation on the phone. The head of department must be in possession of good communicative, social and intercultural skills to reach a conclusion that accommodates the needs of both companies. The head of the department ought to also have the language skills to make an accurate summary of the termination of the agreement.
\end{abstract}

Situation 2: Searching the Internet

Communication situation: summary of online information on markets and / or competitors, gathering of internal information

Location: Office (cement production factory)

People: Assistant to the Head of Purchasing and Procurement Department.

Critical factors for success: The assistant should have sufficient reading skills to find and understand the right information in foreign language for the "petcock" raw material. In this case the assistant should use the strategic knowledge to browse and have a quick reading of the available material to find out which text is needed and which is not. Further, the assistant must summarize the text and select the parts useful to be further translated for the head of the department.

Table 5: Most demanded situations

Critical situation 3: The bankrupt client

Communication situation: keeping information with a bankrupt customer, attempting to recover outstanding payments.

Location: office, cement factory.

People: Assistant to the Head of sales department

Challenging factors: The situation has become critical because of the issue's level of complexity. The assistant needs prior information in order to assess the situation properly and collect the information needed to keep the conversation going, asking the right questions, etc. At this point, language skills, legal knowledge and social and intercultural skills are needed. Intercultural skills here refer to knowledge of culture e.g. about ways to terminate the deal with a bankrupt business (knowledge of the country and its legislation). It also needs cross-cultural competences in order to correctly assess the situation and respond properly. Further, in the next phase, she needs language skills to summarize the conversation content with the liquidator and report it to the general manager in the English language. This case requires in particular good mediation skills, only a highly skilled person can perform such a task.

Details: The international client has declared bankruptcy. However, there are outstanding payments and the company has had business deals with the bankrupt client. The assistant has the duty to contact the liquidator / supervisor to get information on the properties left over from bankruptcy. She should also determine the extent to which its company ranks in this procedure in order to evaluate the probability of recovering part of the debt. It needs to process the information and pass it to the company's legal office or a lawyer who is in charge of representing the company.

Snap shot

Personal information.

My name is Z. nationality: Albanian. I work in the sales department in a manufacturing plant where I hold the position of assistant in export sales. I am 31 and I have been working in this company for 6 years. Before that, I worked in an agro-processing company as a sales agent. I have studied Business Management, and hold a Bachelor and Master diploma.

One working day

First thing I do (after I have a morning coffee) is checking the electronic mail. Today I had two 
messages demanding immediate action, but before I got involved I got a call (at 8:30 in the morning) from a customer who asked for a cement load. He wanted a load as soon as possible since they had run out of cement at the construction site where they were working. It was urgent. I told him I would check if it could be done and I would get back at him again. I had to call the warehouse colleague and ask if there was enough cement to ship but he replied negatively. Thus, I made a call to my colleagues at the other factory. I sent some e-mails to the other factory and made a call about lunch loads. Meanwhile, I received a call from another customer complaining about a shipment which was due for dispatch 2 days ago.

To sum it up, I spent most of the day with correspondence, e-mail, letters and phone call. In our department we have to deal with requests, check the stock, communicate with colleagues in the sales department and warehouse, get info on the state of the goods, negotiate the shipping terms and trade credit.

\section{Language}

About $25 \%$ of the communication has to do with writing e-mail, letters is in English, the working language we use with almost all foreign companies. Usually I have about four or five telephone conversations in English a week, usually in connection with shipment complaints. Sometimes we have problems communicating, especially when the person on the other end of the phone is not native in English language. In few cases, contracts contain legal problems. In these cases I pass it on to my boss or department of legal affairs. In general, we get by, especially because we have a colleague who has lived in England for several years. If things get harder, we ask him to act as an interpreter/translator.

\section{Conclusion}

A language teacher cannot outline and design and an effective and tailored ESP course based on someone's intuition. The CEF professional profile is a really useful tool for ESP practitioners since it supplies the necessary information in order to prepare teaching materials for classes of different professional domains. This research used the latest language needs analysis method outlined in CEF Professional Profiles project in order to develop the profile for Business graduates aiming thus to provide an answer of what has to be taught in a principled manner. It is a practical tool for an ESP practitioner since it presents the main genres used and the key aims of communication of a particular domain. Moreover, similar profiles for other fields can be created so that we eventually have plenty of data that would cover the needs for most courses aiming at professional communication. It has also reflected that CEF profiles are flexible and evolve according to the requirements and particularities of each professional field, which is a new perspective on how those profiles can be used. Lastly, apart from offering an up-to-date knowledge on the business graduates employed in international trade companies, this article aims at giving motivation to future researchers who wish to create profiles for other domains. Therefore, more ESP teachers and course designers can elaborate on the research presented and get encouraged to create further profiles that will suit their particular teaching needs.

\section{References}

Berwick, R. (1989). Needs assessment in language programming: from theory to practice. In: Johnson, R. K. (Ed). The second language curriculum. Cambridge University Press, 48-62.

Brindley, G. (1989). The role of needs analysis in adult ESL program design. In: Johnson, R .K. (Ed). The second language curriculum. Cambridge University Press, 63-78.

Common European Framework of languages. (2001). https://www.coe.int/t/dg4/linguistic/Source /Framework_EN.pdf.

Dudley-Evans, T. \& St. Johns. (1998). Developments in AQS: A multidisciplinary approach. 4th ed. Cambridge University Press.

Huhta, M., K. Vogt, E. Johnson and H. Tulkki. (2013). Needs Analysis for Language Course Design: A Holistic Approach to ESP. Cambridge University Press. 
Huhta M, Vogt Esko K, Johnson, Tulkki H. (2002). Needs analysis and the CEF Professional Profiles in ESP. Cambridge University Press. ttp://assets.cambridge.org/97805211/28148/excerpt/9780521128148 excerpt.pdf.

International Teacher Training Organization. EFL Teaching terminology and glossary. (2005): http://www.teflcertificatecourses.com/tefl-articles/eflteaching-terminology.html.

Hutchinson, T. and Waters, A. (1987). English for Specific Purposes: A learning-centred approach. Cambridge University Press. 